\section{Os riscos genômicos e a responsabilidade pessoal em saúde}

\author{
Luis David Castiel, ${ }^{1}$ \\ Maria Cristina Rodrigues Guilam, ${ }^{2}$ \\ Paulo Roberto Vasconcellos-Silva ${ }^{3}$ \\ e Javier Sanz-Valero ${ }^{4}$
}

Em geral, o discurso da saúde pública classifica os riscos em duas categorias: os ambientais e aqueles resultantes de determinados estilos de vida (1). O evento das pesquisas genômicas, porém, fez emergir uma terceira categoria: o risco genético, uma nova entidade explicativa de saúde e doença. Se os fatores de risco ambientais estão relacionados às exposições sofridas pelo indivíduo, em geral de maneira involuntária, e os estilos de vida são, aparentemente, escolhas ou opções que o indivíduo adota voluntariamente, o risco genético é algo que está no corpo do indivíduo e do qual o indivíduo não pode se dissociar: é uma categoria de risco corporificado (2).

\section{Genômica, epidemiologia e saúde pública}

Antes de prosseguir, é importante deixar claro que não se trata aqui de fazer uma crítica irresponsável a indiscutíveis benefícios veiculados pelos avanços dos conhecimentos genômicos e de suas aplicações, mas sim assinalar possíveis insuficiências em termos éticos e sociais, para que tais limitações sejam reconhecidas, enfrentadas e superadas. Ainda, é essencial assumir que as pesquisas genômicas abordam eventos multidimensionais encadeados em vários níveis, tanto em termos verticais como horizontais, que se transformam com enorme rapidez em função da alta aceleração dos domínios biotecnológicos, onde se mesclam fortes e variados interesses de indivíduos e instituições, tanto públicas como privadas (3).

O termo genômica foi criado há praticamente duas décadas. Designa um modo de lidar com as questões do "genoma" - palavra que, por sua vez, teria sido usada pela primeira vez em 1920, originada de uma fusão das palavras gene e cromossomo, para descrever apenas um dos aspectos do campo da genética (4). Esse aspecto cresceu de modo gigantesco e se tornou independente do campo de onde surgiu, tornando-se ele próprio um domínio disciplinar; agora, ocupa progressivamente o terreno que antes lhe deu origem.

Se essa sinopse por demais simplista remete ao conhecido tema da criatura que subjuga seu criador, há especificidades que merecem ser consideradas. Os antigos terrenos da genética ficaram incomodamente marcados por notórios estigmas eugênicos. Uma das formas de se livrar dessa pecha seria, de alguma forma, desvincular-se dessas marcas. Assim, a genômica é a nova genética, que seria 
distinta da velha por afastar-se, em tese, da intimidade desta última com notórias e trágicas propostas totalitárias (5).

Como é sabido, a capacidade de difusão da genômica é muito intensa e veloz. Inevitavelmente, ela se aproximou de disciplinas e campos de pesquisa pertencentes à saúde pública e à epidemiologia. Com isso, assistimos à aparente consumação de uma aproximação progressiva que teria se delineado com a chamada epidemiologia molecular do início dos anos 1990 e que agora assumiria um novo patamar com a genômica populacional. Esse novo patamar teve um momento inaugural com a criação da rede de epidemiologia do genoma humano (Human Genome Epidemiology Network, ou HuGE Net) em 1998. A HuGE Net é um esforço de colaboração entre indivíduos e instituições voltados à avaliação dos efeitos das variações do genoma humano na saúde das populações. Uma função dessa rede foi a de produzir protocolos, recomendações e técnicas de verificação e incorporação de informações epidemiológicas acerca do genoma humano, contemplando desde a pesquisa primária em genômica até a disseminação, para efeitos de política e práticas, em relação, por exemplo, à produção de testes genéticos (6).

As metas dos megaempreendimentos dessa nova faceta epidemiológica na atualidade se dirigem a ampliar o conhecimento das bases genéticas do desencadeamento, da evolução e da resposta aos tratamentos de muitas doenças. O propósito unificador de tantas e diversas atividades tende a ser enfeixado sob a égide da melhoria dos recursos preventivos, diagnósticos e terapêuticos (7).

Mais especificamente, no caso das doenças infecciosas, por exemplo, o seqüenciamento dos genomas de agentes microbianos patogênicos pode proporcionar informações essenciais para construir testes diagnósticos, detectar mecanismos de virulência e determinar as formas de escapar da ação das defesas dos hospedeiros. Pelo lado destes últimos, os estudos genômicos podem trazer mais conhecimento às variações de suscetibilidade e de reações às infecções humanas. Tais elementos podem gerar condições para a produção de vacinas efetivas para doenças como a AIDS, a tuberculose e a malária, entre outras. As pesquisas do genoma podem trazer melhores entendimentos dos mecanismos imunitários envolvidos nos respectivos processos moleculares etiopatogênicos e viabilizar a criação de vacinas ou antibióticos mais efetivos (8).

No entanto, diante de enfermidades genéticas (e também crônico-degenerativas), são vigorosos os discursos de responsabilização pessoal. Por exemplo: uma empresa estadunidense de biotecnologia (Genzyme) faz questão de ressaltar a responsabilidade genética dos pais judeus de ascendência Ash- kenazim com vistas a conhecer, mediante testes genéticos, a constituição gênica dos filhos em função do risco de doenças prevalentes nessa população (9). Dentro do contexto dos potenciais interesses econômicos que subjazem aos intentos educativos de uma empresa nesses moldes, é importante perceber a atmosfera culpabilizadora em que essa argumentação ocorre.

\section{Risco genético como risco corporificado}

Os estilos de vida, foco prioritário da promoção e educação em saúde, podem ameaçar a integridade moral do indivíduo por estarem associados (aparentemente) a escolhas e atitudes equivocadas. Quanto aos riscos ambientais, sua ocorrência não pode ser imputada ao indivíduo, uma vez que são riscos externos, impostos pelo ambiente (2). Já os riscos corporificados abrangem os riscos que o indivíduo carrega em seu corpo-um gene anômalo que pode trazer doença, atual ou futura, e que redime o indivíduo de culpa por seu comportamento ou por seu adoecimento. Estão incluídos na categoria de risco genético indivíduos portadores de genes anômalos ou pertencentes a famílias onde há a ocorrência de um defeito genético. Como, até o momento, não é possível alterar uma informação genética "equivocada", as escolhas do indivíduo em risco genético são bastante limitadas: submeter-se a testagem genética ou, em se tratando de uma gravidez de risco para malformações, aceitar o diagnóstico genético pré-natal (10).

Em duas situações as aplicações clínicas da pesquisa em genética molecular já estão estabelecidas: no diagnóstico pré-natal e no rastreamento de desordens relacionadas a um único gene.

O diagnóstico genético pré-natal envolve um conjunto de exames que possibilitam a detecção de malformações congênitas intra-útero, como os defeitos de fechamento do tubo neural e as anomalias cromossômicas, das quais a mais conhecida é a síndrome de Down. Enquanto o desenvolvimento futuro da genética aplicada à medicina é difícil de prever com precisão, podemos antever que logo será possível a testagem para avaliar a predisposição genética a uma variedade de doenças, como diabetes, doenças cardiovasculares, alguns tipos de câncer e mesmo alguns comportamentos humanos, como o alcoolismo.

O risco genético apresenta-se como mais uma possibilidade de definição de indivíduos em risco. Esse risco corporificado, contra o qual o indivíduo pode fazer muito pouco e pelo qual ele não pode ser responsabilizado, estende-se do plano individual para a família. A ocorrência de uma doença genética em um dos membros coloca para ele mesmo e 
para os outros questões difíceis, tais como: quem quer saber? Quem precisa saber? Como serão as decisões reprodutivas a partir dessa informação?

Em que pese a relativização de seu poder preditivo pelos próprios cientistas, a idéia de que a identificação do perfil genético dos indivíduos traria soluções para doenças e comportamentos humanos torna-se cada vez mais presente no imaginário social. As pesquisas genéticas e suas possíveis aplicações apresentam-se à sociedade como uma grande promessa para solucionar problemas em diversas áreas do conhecimento. A dúvida que inevitavelmente se coloca se dirige à respectiva capacidade de cumpri-las em grau compatível com tais promessas e tendo em conta o surgimento de efeitos eticamente indesejáveis.

\section{A genômica como a nova panacéia universal}

Segundo Melzer e Zimmern (11), na imaginação do público leigo, a ciência genética já nos colocou em um mundo onde testes e tratamentos estariam disponíveis para a maioria das doenças. Os resultados reais e as possibilidades de intervenção, no entanto, são bem mais modestos. Com exceção das doenças de alta penetrância, relativamente raras, e das doenças vinculadas a um único gene, os testes genéticos diferem muito pouco de outros testes médicos no tocante ao que podem realmente oferecer: a evidência de risco estatístico, tão-somente.

O estereótipo de um gene determinante de cada doença é insatisfatório quando aplicado a condições multifatoriais e mesmo quando aplicado a doenças monogênicas, as quais muitas vezes mostram considerável variação quanto às manifestações clínicas. As talassemias, por exemplo, mostram uma grande variação fenotípica, e é comprovada a variedade de fatores - ambientais e genéticos- que influenciam o seu desenlace. A busca por genes implicados em patologias fez com que a fronteira entre normal e patológico se desvanecesse, havendo uma tendência cada vez maior de se incluir na categoria de "doentes" pessoas sem manifestações clínicas ou com manifestações muito discretas.

Do ponto de vista clínico, as informações genéticas têm duas amplas aplicações: 1) modificar os cuidados médicos prestados ao indivíduo; e 2) tornar possível o aconselhamento a casais que desejam ter filhos.

Em função do espectro de possibilidades ligado a fenômenos como penetrância e multifatorialidade, coloca-se, por parte dos médicos geneticistas, a preocupação de que as testagens genéticas se dêem no contexto da clínica e que sua realização possa vir a ter um saldo positivo para os pacientes. A ocorrência de testagens genéticas desvinculadas do atendimento clínico é uma possibilidade real, que pode ser responsável por mecanismos de iatrogenia simbólica e social importantes. O que pode fazer um indivíduo com um resultado positivo de teste de suscetibilidade para um tipo específico de câncer, por exemplo, fora de uma perspectiva clínica ou de aconselhamento? Ou ainda, o que pode significar a disponibilização comercial de testes relativos a características humanas complexas para aplicação em embriões in vitro em procedimentos de diagnóstico genético pré-implantatório? Ou a utilização de testes genéticos para a predição de uma tendência a doenças crônicas e para definir seguros de saúde? (12).

Em um determinado nível, a ciência genética está nos forçando a reexaminar o conceito de normalidade, por mostrar que o genoma de cada um é único e que todos somos de alguma maneira "anormais". Cada um de nós carrega variações genéticas, muitas das quais não têm impacto detectável em circunstâncias normais. Algumas vão indubitavelmente alterar o nosso risco de doença, enquanto outras, ao encontrarmos um parceiro que carregue uma variação similar, podem resultar no nascimento de uma criança com uma doença genética recessiva.

No entanto, ainda que, em realidade, as aplicações clínicas das testagens genéticas sejam bastante limitadas, é inegável a força explicativa que o gene adquiriu, tornando-se imaginariamente uma entidade determinista e finalista quanto ao adoecimento e comportamento humanos, criando aquilo que Nelkin e Lindee (13) chamaram de mística do ADN.

\section{Genomização e testagem pré-natal}

Há, sem dúvida, um interesse renovado por explicações biologizantes para os fenômenos saúde e doença, e o discurso que hoje melhor representa esse interesse é o da genética. A tensão entre explicações reducionistas e explicações mais abrangentes sempre existiu na história da medicina. Ao invés da compreensão das diferenças sociais ou ambientais, a genética justifica as diferenças com base em características "naturais" ou "predeterminadas", para diferenciar "eles" de "nós" (14).

O discurso genético tem, por um lado, o poder de gerar um senso de fatalismo e de isentar o indivíduo de responsabilidades por suas ações, pois, afinal, os culpados seriam os seus genes. Por outro, esse discurso reforça um julgamento moral, uma vez que define os "bons" e os "maus" genes. É interessante pensar que, muito antes da hereditariedade ser explicada em bases biológicas - hoje, bases genéticas-, as noções de "sangue" e parentesco eram usadas para explicar as desigualdades sociais. A su- 
perioridade do sangue azul e a alusão a sementes más são temas historicamente importantes e que refletem interesses sociais e familiares (15).

Claramente, o gene na cultura popular não é uma entidade biológica. Embora ele se refira a uma construção biológica e derive o seu poder cultural do conhecimento científico, o seu significado simbólico ultrapassa definições biológicas. O gene é um símbolo, uma metáfora, uma maneira conveniente de definir pessoa, identidade e relações, é uma forma de falar sobre culpa e responsabilidade, poder e privilégio, status intelectual e emocional.

A genética nos impele, portanto, a alterar a nossa percepção sobre nós mesmos e o outro, sobre normalidade e anormalidade. Essa mudança encontra uma visibilidade particular na área da reprodução, considerando-se o impacto das testagens pré-natais e das triagens em mulheres.

De qualquer forma, não é absurdo cogitar que a disponibilização progressiva de testes genéticos, aliada ao clima de responsabilização pessoal, possa elevar as pressões para a realização de tais exames diagnósticos. Como ilustração, vale assinalar que a responsabilização de parentes consangüíneos em relação a seus descendentes no que se refere a doenças crônicas pode, inclusive, ampliar-se, em termos de incluir os avós como responsáveis por doenças dos respectivos netos. Um indício dessa possibilidade aparece em uma investigação que buscou verificar a associação entre a asma infantil e o hábito de fumar da mãe e da avó antes, durante e depois da gravidez. Chegou-se à conclusão de que o hábito de fumar da mãe e da avó estava associado a um aumento do risco de asma infantil. O estudo inclui a possibilidade de intervenção de fatores genéticos nessa vinculação (16).

Por outro lado, para além dos discursos, bem justificados ou não, que explicitam e sustentam a racionalidade biocientífica dos grandes empreendimentos de investigação genômica e de produção de tecnologia, podem-se perceber certos deslocamentos retóricos que acompanham esses movimentos. Não cessam de surgir novos substantivos e adjetivos que procuram designar parcerias e hibridizações, disciplinares ou não, com vistas a integrar conteúdos provenientes da combinação de múltiplos setores de investigação, por exemplo, epidemiológicos, genéticos e clínicos, sob a forma de projetos públicos, privados, acadêmicos e empresariais.

\section{A nova retórica da responsabilidade genômica}

Um exemplo dos novos substantivos é evidente nas novas subdisciplinas que envergam o sufixo "ômico", acompanhando a grande matriz genômica, e que se voltam a estudar os produtos, expressões e interações gênicas: "proteômica", "transcriptômica", "metabonômica", "nutrigenômica" ou "farmacogenômica" (17). Os adjetivos utilizam o recurso de adjudicar o predicado "novo" a conhecidas disciplinas. A nova epidemiologia genética (18) seria aquela que procura compatibilizar impactos recíprocos entre disciplinas.

A própria genômica consiste em um campo de efervescente geração de discussões. Na última década e meia, houve uma proliferação de matérias, estudos, artigos, livros e relatórios sobre o tema, com um variado espectro de posições. Os pontos de vista que nos parecem mais proveitosos em termos críticos - propósito deste texto- são aqueles que procuram localizar sociologicamente as questões de responsabilidade emanadas a partir da chamada nova genética. Mas, sem dúvida, proliferam aqueles que enfatizam posições individualistas, que ressaltam a necessidade de se difundir informações com vistas à "escolha informada" dos pacientes, de modo não-diretivo, de maneira a respeitarem-se os seus "desejos" e "necessidades" e, também, os de suas famílias, em função de uma determinada noção de autonomia-algo que Petersen (19) discute sob o ângulo do ideal de uma cidadania genética.

Uma variação dessa perspectiva de responsabilidade genética pode se apresentar sob o manto mais diáfano da solidariedade genética. Em um informe de 2002 (20), um conselho independente do governo britânico que se dedica a abordar aspectos sociais e éticos em genética humana afirma que

Compartilhar informação genética pode gerar oportunidades para ajudar outras pessoas e para que outras pessoas nos ajudem. Temos um interesse comum nos benefícios que a pesquisa genética possa trazer. Portanto, propusemos o conceito de solidariedade genética e altruísmo [negrito no original]. Isso sustenta a idéia de que, por exemplo, ainda que ninguém deva se sentir forçado a participar de uma pesquisa genética, quando tomam essa decisão, as pessoas devem estar conscientes de que, ao participar, podem ajudar aquelas que sofrem de doenças [tradução dos autores]. (Pp. 6-7)

Petersen (19) assinala que essa tendência não é nem uniforme nem absoluta; há, inclusive, movimentos de descrença e resistência por parte de grupos de mulheres, minorias étnicas e portadores de déficit físico, particularmente no que se refere à chamada reprogenética-a tecnologia genética dirigida à reprodução. Ainda, para o sociólogo australiano, tal conceito refletiria um deslocamento do ideal comunitário embutido na idéia de solidariedade social, que se baseava na coesão do tecido social com a predominância de interesses compartilhados. 
Além disso, na solidariedade genética, tentase replicar uma ordem de sentimentos e laços sociais mais densos para contextos onde predominam fluidez e transitoriedade, com alto grau de incompatibilidade com tais padrões de configuração comunitária. É possível, inclusive, interpretar a designação de "solidariedade" como um eufemismo que atenua a idéia incômoda de "obrigação".

\section{Risco, responsabilidade e genomização epidemiológica}

Com a epidemiologia genômica, estamos presenciando um momento em que a noção de genes como causas suficientes de doenças (genetização) parece estar passando por uma significativa inflexão. Para além de uma ênfase intensiva que nos levava a pensar em genes responsáveis por determinadas doenças, adentramos uma nova fase, ensejada pela epidemiologia do genoma humano, que também encara os genes como causas necessárias de doenças (genomização epidemiológica). Se as doenças sempre apresentam um componente genético, mesmo que débil, tentar abordá-lo e neutralizá-lo é benéfico em termos de saúde pública. Por essa razão, a epidemiologia genômica estuda grandes contingentes populacionais, de forma a assegurar aos resultados dessas investigações a robustez necessária para detectar variações sutis.

Ainda assim, infelizmente, várias das críticas feitas à genetização (21) continuam valendo para a genomização, sobretudo se imaginarmos a agressividade com a qual algumas empresas de biotecnologia desenvolvem testes para a detecção de genes para doenças crônicas prevalentes (como doenças coronarianas, hipertensão arterial, diabetes e acidentes vasculares cerebrais). Sabe-se que tais doenças são, em grande parte, dependentes do ambiente, justificando medidas que visam atuar nos aspectos extragenéticos. Nesse contexto, a genetização está a um passo dos discursos de responsabilização pessoal e culpabilização virtual das vítimas do risco.

Isso porque não é absurdo imaginar o potencial de tais testagens no sentido de atualizar, no âmbito da promoção da saúde genômica, a criação de um novo estatuto que represente bem a virtualidade de nossa época: a responsabilização pela probabilidade de algo que ainda não ocorreu, mas pode acontecer em função de certos indícios. Ou, em termos mais usuais e enfáticos: diante das evidências de risco genético, a previsibilidade de nosso destino, ao invés de aumentar, como se pretendia, acaba por contribuir para a sensação de incertezauma construção híbrida própria da virtualidade. Está longe de ser simples a gestão de múltiplas escolhas em um contexto abstrato em que se mesclam elementos manifestos e latentes com vistas a evitar desfechos indesejáveis. Ademais, os resultados positivos dos testes com foco na dimensão genética das doenças crônico-degenerativas de um indivíduo podem também afetar os demais membros da família, tanto no sentido de virem a conhecer aquilo que prefeririam não saber, ou, ao contrário, de não lhes ser oferecida ou viabilizada a possibilidade de acesso a tal informação.

A genomização veiculada pelas testagens genéticas pode levar a uma dupla responsabilização, tanto no sentido de um peso superdimensionado dos fatores genéticos sobre os aspectos sociais e ambientais (para além da exposição a ambientes e contextos de trabalho patogênicos) como em direção ao reducionismo genético e às explicações sociobiológicas do comportamento humano. Neste último caso, isso combina com o arcabouço neoconservador vigente que entende o adoecimento sob o ponto de vista eminentemente individualista e biologicista. Tal perspectiva, como vários autores apontam (21-23), tem afinidade com a primazia globalizante de criação de mercados, com o otimismo biotecnológico como componente fundamental para as práticas de saúde, com o movimento de diminuição do tamanho do estado e com o aumento do controle social através de ações tanto "pan-ópticas" de biovigilância (como na obrigatoriedade de testagens genéticas para a obtenção de emprego) quanto "sinópticas" (24) (como no caso da estimulação individualista de sentimentos de culpa por não se procurar conhecer, para si ou para os familiares, os níveis de risco genômico associados a várias enfermidades).

Esse panorama se ajusta bem com as preocupações em termos da promoção da saúde mediante um estilo de vida saudável. Se, por exemplo, mesmo na ausência da elevação dos níveis de colesterol, são detectadas predisposições genéticas (ainda que débeis) à doença coronariana, também podem-se colocar apelos racionalizantes à responsabilidade individual no sentido de adotar atitudes saudáveis, com consumo ativo de bens e serviços a partir de escolhas supostamente bem informadas. Em outras palavras, instituem-se, para o consumidor, prerrogativas para exercer o seu "direito" de ser informado para decidir e dispor da "liberdade" de escolher tecnologias e conhecimentos com vistas a proteger sua saúde. A opção é balizada pela capacidade de acesso ao consumo e pelo contexto socioeconômico mais amplo. $\mathrm{O}$ que fazer com enormes grupos populacionais que não podem atuar efetivamente como agentes de consumo? Talvez, na melhor das hipóteses, poderão receber ajuda mediante campanhas solidárias. Se isso é cabível, em certa medida, para as necessidades essenciais de sobrevivência, como será o acesso a eventualmente sofisticados e onerosos testes genéticos? Possíveis res- 
postas ainda não parecem estimular expectativas alvissareiras.

Essas dimensões não costumam receber ênfase nos discursos dominantes da "nova" genética, na qual o termo "nova" parece funcionar como indicativo da fronteira entre a antiquada e repressora genética eugenista e a proposta atual, que cada vez mais assume a denominação "genômica", aparentemente progressista e liberadora, que a desvincularia de modo cabal daquela. Enquanto a velha eugenia operava repressivamente via autoridade estatal, a genômica moderna atua sobretudo pelos mecanismos de mercado e usa a linguagem de poder individual e da liberdade de escolha do consumidor.

Agora, é preciso traçar uma breve genealogia das idéias de responsabilidade genética. Podem-se cogitar suas supostas origens a partir dos evidentes avanços técnicos e científicos da genética iniciados nos anos 1970, como a triagem para determinadas doenças e o florescimento de tecnologias de reprodução assistida (25).

A expressão "responsabilidade genética" pode ser compreendida de duas formas que nem sempre estão claramente explicitadas, mas que tendem a se superpor: em termos da esfera gênica de suposta influência causal e em termos de valores morais que envolvem dever e culpabilidade. Aqui se destaca a expectativa dirigida ao indivíduo, que deve administrar prudentemente os seus riscos através de decisões supostamente bem informadas quanto a estilo de vida com base em dados provenientes de exames genéticos (26). Sem dúvida, as idéias eugênicas se inscrevem nesse cenário, mas este não é o local apropriado para desenvolver esse tema complexo. Podese, porém, avançar e apresentar a "nova eugenia" (poderíamos, talvez, denominá-la "eugenomia") como uma proposta de caráter eugênico que se funda no discurso do risco genético. Ou seja, se os resultados de testagens gênicas se configuram em termos de construções probabilísticas de risco genético, esses elementos passam a engendrar novas bases para práticas eugênicas que não mais se dirigem a determinados indivíduos ou grupos bem demarcados (judeus, insanos ou criminosos), mas potencialmente a todos. Veja-se, por exemplo, o fato de toda a gravidez estar passível de ser configurada em termos de risco (27).

Os discursos de responsabilidade genética podem ser encarados teoricamente sob uma perspectiva foucaultiana como um elemento estratégico pertencente à governamentalidade ou governância genética (28). Ou seja, deve-se perguntar como tais conhecimentos e tecnologias são empregados para a regulação de indivíduos e grupos humanos e como as correspondentes práticas médico-sanitárias e seus dispositivos diagnósticos e epidemiológicos atuam como tecnologias políticas e morais. Con- tudo, é possível considerar que a posição de Foucault, mencionada por Coors (28), em relação à genética, seja mais de resistência do que de antagonismo, e mais de especificação do que de indicação de alguma forma maniqueísta e prescritiva de moralidade. Não cabe advogar irresponsavelmente contra os enormes benefícios potenciais do conhecimento genômico. Nossa tarefa é a de tentar estabelecer quais dimensões dos avanços propiciados pela genômica, sob o manto da imparcialidade científica, sustentam e ampliam as desigualdades sociais e subjugam a existência humana como refém biopolítico de informações genéticas.

As práticas eugênicas responsáveis seriam aquelas que mesclam a liberdade reprodutiva individual com a educação e a discussão pública sobre procriação responsável, desde que isso não seja a expressão de desejos relativos a cor de olhos, tipo de pele e de cabelo, tendência à obesidade ou preferências sexuais. Kitcher (29) apóia a noção de que os pais têm o direito de decidir se terão seus filhos após a devida informação, sobretudo em relação a graves doenças genéticas (como aquelas descritas pela empresa Genzyme, entre outras) que irão afetar fortemente a qualidade de vida da criança atingida e provocar profundas dificuldades para a família. Nesses contextos, a questão é estabelecer os limites do que é moralmente admissível. Basicamente, tal diferenciação equivaleria à distinção entre a futilidade do shopping genético (30) e a responsabilização dos pais quanto ao patrimônio genético das gerações vindouras. Um dos aspectos ocultos dessa discussão é o risco de se equacionar "ser alguém" com "ter algo" (31).

A responsabilidade genética também aparece nas concepções de Novas e Rose (32) sobre as mudanças da subjetividade na contemporaneidade, mas destituídas de uma perspectiva crítica. Para esses autores, o indivíduo em risco genético seria o elemento-chave no aparecimento da nova genética molecular. Porém, a possibilidade de recatalogar patologias em um eixo genético não geraria fatalismo, mas sim a obrigação de agir preventivamente, ou seja, responsabilidade genética. As linguagens e técnicas genéticas configurariam uma individualidade somática a partir desses elementos biológicos, de modo a participar da geração de uma "qualidade responsável e empreendedora do ser".

Desse ponto de vista, o indivíduo-paciente deve ser um aliado do médico, um protoprofissional- $\mathrm{e}$ assumir a sua parte de responsabilidade na melhora (32). Em outras palavras, ao se tornar parte de uma rede genética, o indivíduo em risco genético teria, em tese, condições de reavaliar as suas relações familiares e íntimas em termos de risco e hereditariedade, de modo, inclusive, a conformar o seu estilo de vida nesses termos. 
Essa racionalidade pode ser entendida sob a perspectiva da "governança genética", uma vez que há um imperativo de se escolher a prevenção à doença de modo a subverter os preceitos de nãoinfluência, autonomia e consentimento informado que deveriam caracterizar o aconselhamento genético. No decorrer da transmissão de conteúdos e de conhecimentos acerca dos riscos genéticos entre especialistas e usuários dos serviços, há estímulos que sustentam a noção de indivíduo autônomo que, através de sua capacidade de escolha, aceita assumir a responsabilidade pessoal por si próprio e por seus entes queridos. Para esses autores, tal prática de engenharia de saúde faz parte da manutenção das propostas hegemônicas de produção de conhecimento com vistas à prevenção de doenças em termos da grande relevância de ações responsáveis. Nesse processo, o conhecimento da condição de risco genético de cada um se torna necessário e obrigatório para a prevenção de doença, constituindo-se em uma tecnologia social que produz biossubjetividades ao estabelecer modos de relacionamento do indivíduo consigo mesmo, com a família e com a sociedade.

Outro aspecto discutível em relação à responsabilidade genética proposta por Novas e Rose (32) se refere aos efeitos do surgimento do que Konrad define como "pessoas pré-sintomáticas" (33) como resultado das testagens para doenças genéticas. Este último estudo antropológico levanta questões sobre os significados culturais relativos à identidade biológica (ou somática) e o estatuto dos conhecimentos de saúde per se. A autora, que trata no artigo do mal de Huntington, afirma que as pessoas leigas podem se tornar "prognosticadores morais". Ou seja, os indivíduos com Huntington na família passariam a considerar como moralmente doentes os familiares que ainda não apresentam os sinais físicos da doença.

Será que cabe cogitar que, no caso de doenças não-genéticas, poderão surgir diagnósticos morais de indivíduos em risco-por exemplo, para as doenças coronarianas, que apresentam alta pontuação nos escores de risco específicos (e não apenas genéticos)? Essa situação equivale ao aparecimento de uma nova condição de doença pré-patológica, um estado intermediário que não é de doença, mas tampouco é de saúde; algo como um estado de purgatório, no qual o possível conhecimento sobre os próprios riscos acaba por criar o paciente preventivo, consumidor de medidas de proteção (33).

\section{Notas finais: a genômica como atividade técnica e científica paradigmática da tardo-modernidade}

A genômica é uma atividade que, em suas redes e vínculos institucionais, políticos e econômicos, organiza-se sob a égide da poderosa indústria biotecnológica-representante privilegiada do capital globalizado. Inclui ramos vigorosos de várias disciplinas das ciências biológicas, da biomedicina (em suas vertentes acadêmica e clínico-assistencial) e, também, da epidemiologia. Esses esforços conjuntos costumam se configurar mediante relações entre atores localizados em distintas nações. Envolvem, também, políticos e gestores preocupados com o aumento dos gastos públicos com saúde e com o bem-estar das populações (25).

Segundo alguns estudiosos do âmbito da economia (34), a nova genética participa da construção de subjetividades neo-liberais que devem dedicarse responsavelmente à gestão privada de riscos à saúde e também colabora para o desenvolvimento de uma economia fundada em tecnoconhecimentos especialmente voltados para o mercado da assistência à saúde. Sob o ponto de vista discursivo, a política privatizante também destaca a privacidade, a escolha individual e a autodeterminação. Um de seus eixos retóricos fundamentais consiste em enfatizar que o formato ideal de organização social é aquele que estabelece como imperativo que os indivíduos autocontrolem as suas existências sem a interferência de outrem. Isso deve se dar no interior de interações sociais mescladas a relações econômicas em que impere a descrença na busca de soluções coletivas. Os problemas são individualizados, fora do alcance de alternativas políticas transformadoras. Nessa contingência, a implementação da agenda globalizada colabora decisivamente para a transformação da saúde em uma mercadoria muito dispendiosa, e da assistência à saúde em um negócio privado que envolve investimentos altos e demanda retornos garantidos (34). Isso, como é sabido, gera uma configuração altamente precária em termos de exclusão social e de saúde pública, sobretudo se encararmos os contextos dos países ditos periféricos, que se debatem em fórmulas para lidar com os ditames econômicos vigentes-e, caso estes fraquejem, para se ajustar a programas econômicos geradores de instabilidade política e social. Fica difícil crer que nesse tipo de contexto seja possível um acesso consistente ao mundo da saúde genômica.

Atualmente, no âmbito sanitário, para que haja qualquer tipo de participação nas decisões envolvendo ciência, tecnologia e riscos, importa que o maior número possível de pessoas conheçam aspectos e detalhes relativos a essas complexas dimensões. Apesar das evidentes dificuldades, os indivíduos devem participar de processos de aprendizagem que levem em consideração as construções leigas existentes, uma responsabilidade dos profissionais de saúde.

Contudo, é preciso esclarecer que essa postura equivale a responder aos problemas da presente etapa da modernidade, seja como se deseje 
chamá-la (tardo-modernidade, pós-modernidade, supermodernidade, hipermodernidade, segunda modernidade, etc.), com respostas que marcaram a fase anterior. Ou seja: quanto mais, melhortécnica, crescimento econômico, ciência, diferenciações funcionais. Ora, uma tal proposição não mais se sustenta, até porque uma hipótese causal para o estado atual das coisas transita pela percepção da relação de frenesi recursivo entre respostas que participam ativamente das perguntas, como assinala Beck (35). Em função das transformações sociais, políticas e econômicas do planeta, está em cheque a perspectiva iluminista européia.

No caso das estratégias da gestão de riscos genômicos em saúde, além dos limites da responsabilidade como discurso que institui a governância, as buscas de solução que clamam por melhores análises técnicas baseadas estritamente na ciência parecem não dar conta das muitas dimensões possíveis para se pensar a condição humana e das concepções do que é apropriado ou não, "bom" ou "mau", mais ou menos arriscado para cada sociedade. Todos esses elementos são constantemente redefinidos e negociados, nem sempre da melhor maneira. A própria ciência não traz respostas satisfatórias para essas questões e, por mais que tente, não dá conta das situações de descontrole, incerteza e complexidade que proliferam, como a que rodeia a discussão acerca dos alimentos geneticamente modificados (36). Lidar com essas controvérsias e conflitos com mais técnica, ciência e globalização econômica até agora não teve os resultados desejados. Longe disso, como tentamos descrever em várias circunstâncias ao longo deste texto. Decerto que as investigações científicas e os estudos técnicos são essenciais para as decisões responsáveis acerca das formas de lidar com os riscos; mas a ciência que não as considera dimensões vinculadas ao contexto está fadada ao fracasso ou então a culpabilizar as vítimas pelas limitações que ela própria, a ciência, possui.

Uma leitura que amiúde escapa desse tipo de perspectiva é a progressiva habilidade do ser humano de orientar-se por objetivos, ou seja, planejar as suas ações em função da realização de projetos. Tal orientação, em si, não seria tema de debates relevantes, como o que aqui se apresenta, se não afetasse a compreensão humana da "natureza das coisas da natureza". O que dizer quando a referida orientação a objetivos planificados se ocupa da espécie humana? $\mathrm{O}$ corpo que temos, ou o corpo que somos, é passível de administração responsável e empreendedora? A natureza das células e tecidos que definem nossa espécie é de nossa propriedade e patente? A estranheza que nos causa a enunciação do termo "autonomia gerencial" talvez se derive justamente da incômoda convivência do segundo elemento ao lado do primeiro. Em outras palavras, a noção de "autogoverno e deliberação segundo a razão esclarecida" destoa da "orientação a objetivos em prol de um patrimônio" (no caso genético).

Em suma, está em jogo a autocompreensão da espécie como projeto liberal que percebe a natureza humana como o coletivo de corpos modificados pela ação humana. O argumento da administração da qualidade responsável e empreendedora do ser já se presta à defesa de uma espécie de eugenia liberal que não hesita em desfazer as bordas tênues entre o que somos como espécie e os corpos que possuímos, pessoalidades administráveis na qualidade de potências geradoras de outros corpos modificados pela ação humana. Libera às escolhas individuais dos consumidores do mercado a seleção dos traços identitários que na verdade não lhe pertencem individualmente, mas sim à espécie humana.

\section{SYNOPSIS}

\section{Genomic risk and personal responsibility in health}

With the advent of genomic research, a new category of risk has emerged-genetic risk-from which an individual cannot be separated. Among the outcomes of this model is a discussion on personal accountability, according to which an individual may both be exempted from events related to certain states of health ("blame it on the genes") or be blamed for those events ("transmitter of disease"). In addition, the search for genes to explain disease erases the line between what is normal and what is pathological, with a growing tendency towards considering individuals with no or very mild clinical manifestations as being "ill." The great emphasis on genomics may lead to both an exaggerated attention to genetics rather than social and environmental factors and to a reductionism that favors sociobiological explanations for human behavior. In addition, in this scenario, the right to information may paradoxically stimulate some to consume goods and services in order to prevent a hypothetical illness that could occur at some point in time as a result of genetic predisposition-goods and services that may not be available to everyone. It is essential that such issues be considered with the same urgency with which the genomic paradigm is being developed.

Key words: ethics, eugenics, genomics, genetic research. 


\section{REFERÊNCIAS}

1. Gabe J. Medicine, health and risk: sociological approaches. London: Blackwell; 1996.

2. Kavanagh AM, Broom DH. Embodied risk: my body, myself? Soc Sci Med. 1998;46(3):437-44.

3. Kaufert PA. Health policy and the new genetics. Soc Sci Med. 2000;51(6):821-9.

4. Knoppers BM, Scriver C. Genomics, health and society. Emerging issues for public policy [monografia]. Toronto: Policy Research Initiative; 2004. Disponível em: http://policyresearch.gc $\mathrm{ca} /$ doclib/genomicbook_e.pdf. Acessado em fevereiro de 2006.

5. Petersen A, Bunton R. The new genetics and the public's health. London: Routledge; 2002.

6. Khoury MJ, Millikan R, Little J, Gwinn $\mathrm{M}$. The emergence of epidemiology in the genomics age. Int J Epidemiol. 2004; 33(5):936-44.

7. Palmer LJ. The new epidemiology: putting the pieces together in complex disease aetiology. Int J Epidemiol. 2004; 33(5):925-8.

8. Chokshi DA, Kwiatowski DP. Ethical challenges of genomic epidemiology in developing countries. Genomics Society Policy. 2005;1(1):1-15.

9. Genzyme Genetics. Massachusetts: Genzyme Corporation; c 2002-2005. Information for patients. Disponível em: http://www.genzymegenetics.com/ patients/gene_p_patient_home.asp Acessado em fevereiro de 2006.

10. Kenen RH. The at-risk health status and technology: a diagnostic invitation and the 'gift' of knowing. Soc Sci Med. 1996; 42(11):1545-53.

11. Melzer D, Zimmern R. Genetics and medicalization. BMJ. 2002;324(7342): 863-4.

12. Correa MV. Novas tecnologias reprodutivas. Limites da biologia ou biologia sem limites. Rio de Janeiro: Eduerj; 2001.

13. Nelkin D, Lindee MS. DNA mystique: the gene as a cultural icon. New York: Freeman and Co; 1995.
14. Lupton D, McCarthy S, Chapman S. Panic bodies: discourse on risk and HIV antibody testing. Sociol Health Illn. 1995;17(1):89-108

15. Paul DB, Spencer HG. The hidden science of eugenics. Nature. 1995;374(6520):302-4

16. Li YF, Langholz B, Salam MT, Gilliland FD. Maternal and grandmaternal smoking patterns are associated with early childhood asthma. Chest. 2005;127(4): 1232-41.

17. Khoury MJ, Millikan R, Little J, Gwinn $\mathrm{M}$. The emergence of epidemiology in the genomics age. Int J Epidemiol. 2004; 33(5):936-44.

18. Davey-Smith G. Genetic epidemiology: an 'enlightened narrative'? Int J Epidemiol. 2004;33(5):923-4.

19. Peterson A. Genetic citizenship [monografia]. Plymouth: Faculty of Social Sciences and Business, University of Plymouth. Disponível em: http:/ /www.lse. ac.uk/collections/BIOS/docs/Alan Petersen.pdf. Acessado em fevereiro de 2006.

20. Human Genetics Commission. Inside information. Balancing interests in the use of personal genetic data [monografia]. London: Department of Health. Disponível em: http://www.hgc.gov.uk/ UploadDocs / DocPub / Document / insideinformation_summary.pdf. Acessado em fevereiro de 2006.

21. Willis E. Public health and genetics: challenges for the social sciences [monografia]. Adelaide: School of Social Science, La Trobe University; 2000. Disponível em: http://www.ssn.flinders. edu.au/soci/staff/riaz/genome project/ 4.htm. Acessado em fevereiro de 2006.

22. Lupton D. The imperative of health: public health and the regulated body. London: Sage Publications; 1995.

23. Robertson A. Biotechnology, political rationality and discourses on health Health. 2001;5(3)293-309.

24. Bauman, Z. Liquid love: on the frailty of human bonds. London: Polity Press; 2003.
25. Kerr A, Cunningham-Burley S. On ambivalence and risk: reflexive modernity and the new human genetics. Sociology. 2000;34(2):283-304.

26. Lemke T. Disposition and determinismgenetic diagnostics in risk society [monografia]. Oxford: The Sociological Review. Disponível em: http://www. thomaslemkeweb.de/engl.\%20texte/ Disposition.pdf. Acessado em fevereiro 2006.

27. Lemke T. Genetic testing, eugenics and risk. Critical Public Health. 2002;12(3): 283-90. Disponível em: http://www. thomaslemkeweb.de/engl.\%20texte/ Genetic\%20Testing\%20II.pdf. [DOI: 10 . 1080/09581590210153399]

28. Coors ME. A Foucauldian foray into the new genetics: bioethics and the later Foucault. J Med Humanit. 2003;24(3-4): 279-89.

29. Kitcher P. Lives to come-the genetic revolution and human possibilities. New York: Free Press; 1997.

30. Habermas J. O futuro da natureza humana. São Paulo: Martins Fontes; 2004.

31. Fromm E. Ter ou ser. Rio de Janeiro: Zahar; 1979.

32. Novas C, Rose N. Genetic risk and the birth of the somatic individual. Econ Soc. 2000;29(4):485-513.

33. Konrad M. Predictive genetic testing and the making of the pre-symptomatic person: prognostic moralities amongst Huntington's-affected families. Anthropol Med. 2003;10(1):23-49.

34. Mykitiuk R. The new genetics in the postKeynesian state [monografia]. Disponível em: http://www.cwhn.ca/groups/ biotech/availdocs/15-mykitiuk.pdf. Acessado em fevereiro de 2006

35. Beck U. Un nuevo mundo feliz. La precariedad del trabajo en la era de la globalización. Madrid: Paidós; 2000.

36. Finucane ML, Holup JL. Psychosocial and cultural factors affecting the perceived risk of genetically modified food: an overview of the literature. Soc Sci Med. 2005;60(7):1603-12. 